\title{
波浪の履歴特性を取り入れた海岸構造物の被災発生予測に関する研究 Disaster Occurrence Prediction for Coastal Structures using Characteristics of Wave history
}

\author{
斎藤武久 ${ }^{1} \cdot$ 松原卓也 $^{2}$ \\ Takehisa SA ITOH and Takuya M ATSUBARA
}

\begin{abstract}
A method to predict disaster occurrence of costal structures is examined by refereeing the repeat disaster occurrences of coastal structures at locations close to each other. Significant wave height data from N OW PHAS is used to make a model of wave history, then maximum wave height during each storm, duration of storm and the flow rate of wave overtopping at the maximum wave height are used as key factors and the time function is also introduced to reduce wave energy and flow rate of wave overtopping at the time retroactive from the moment of disaster occurrence. The accumulation value of the wave energy and the flow rate of wave overtopping with the time function are carried out to judge of disaster occurrence of seawalls in Ishikawa coast, and the possibility of the index to explain the disaster occurrence is discussed.
\end{abstract}

\section{1はじめに}

海岸堤防・海岸護岸などの海岸保全施設は，背後域の 生活や産業の拠点への要として, その整備が継続的に行 われてきている。ただし，施設の構造は例えば緩傾斜護 岸や直立護岸に見られるように, 構造体の海側部が砂や 砂利, さらにその上がコンクリート構造となる複合構造 となり, 波浪との相互干渉問題, 特に砂や砂利の移動特 性の把握は極めて重要な課題と言える.

これに関連して，例えば，大河原ら（1983）および加 藤ら（2011）は，海岸堤防・護岸の被災事例に関する害 態調査を行い被災機構の検討を行っている. さらに, 山 本ら (2005，2009，2011）は海岸施設の破壊機構につい て分析し構造物前面での洗掘や吸出しに関連する外力要 素の組み合わせにより破堤限界值として越波流量と前面 地盤のせん断抵抗力の関係を提案している。一方で, 実 務的には, 砂や砂利などの安定解析を個別に行った実験 結果より援用しているのが現状と言える.

ところで, 海岸保全施設に一旦被災が発生した場合, 多くの場合原型復旧が基本であり再度繰り返し被災が発 生しているケースは少なくない，例えば，図-1に示す石 川海岸小松・片山津工区では，1980年から2007年までの 間に43件の被災発生が報告されている（北陸地方整備局 事業評価監視委員会, 2014)。海岸構造部の被災は被災 時の海象条件から分析されるが, 現象は砂や砂利さらに コンクリートからなる複合構造と波浪との相互干渉問題 となるためそのメカニズムを施設構造の詳細と結びつけ て解釈することは必ずしも容易ではない，ただし，多く

\footnotetext{
1 正会員 博(工) 金沢大学教授 環境デザイン学系

2 金沢大学大学院環境デザイン学専攻
}

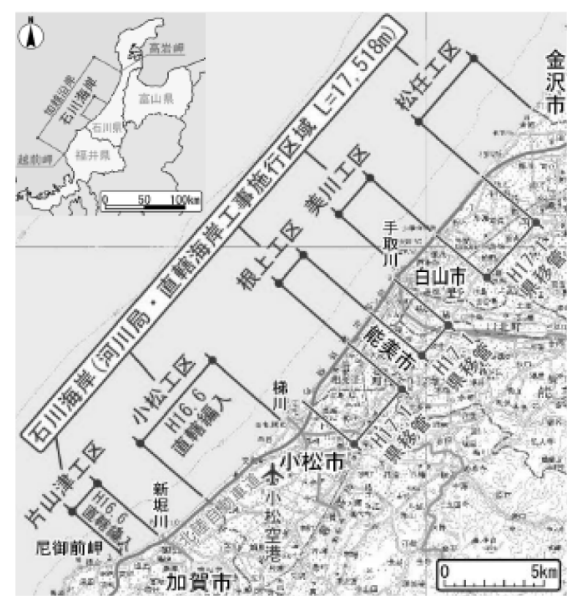

図-1 実石川海岸小松・片山津工区の概要(北陸地方整備局事 業評価監視委員会, 2014)

の場合設計波高に満たない波浪の来襲で被災が発生して いること, さらに, 暴浪の繰り返しの来襲で経年的に施 設が強度を失う可能性があることに着目した場合, 来襲 波浪の履歴特性を考慮することで被災の発生予測を議論 できる可能性がある。本研究では, 従来の設計波を用い た構造安定解析に基づく被災発生の判断とは別に, 来襲 波浪の履歴特性を組み入れて被災発生指標を導出した新 たな被災発生予測手法を提案することを目的とする。

\section{2. 対象領域}

\section{(1) 対象海岸の概要}

本研究では, 繰り返し海岸構造物の被災報告されてい る石川海岸の小松・片山津工区を対象海岸とする. 石川 海岸は図-1に示すように, 金沢市の西方に位置し, 南西 の尼御前岬から北東の白山市と金沢市の市境までに渡る 直線的な砂浜海岸であり加賀沿岸の一部をなしている. 


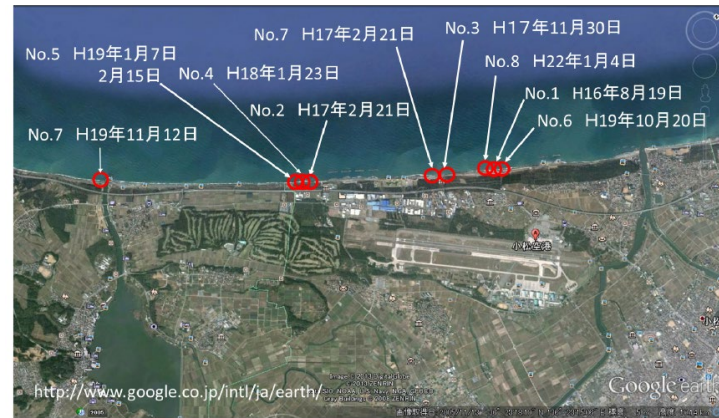

図-2 最近の石川海岸小松・片山津工区における海岸保全施 設の被災発生箇所と発生日

表-1 最近の石川海岸小松・片山津工区における海岸保全施 設の被災発生箇所, 発生日および被災形態

\begin{tabular}{|c|c|c|c|c|c|c|}
\hline \multicolumn{3}{|c|}{\begin{tabular}{ll|} 
No 0 発生年月日 \\
\end{tabular}} & \multirow{2}{*}{\begin{tabular}{|c|} 
発生場所(小松市) \\
$\begin{array}{c}\text { 安宅新町地先 } \\
\text { (A区間) }\end{array}$ \\
\end{tabular}} & \multirow{3}{*}{\begin{tabular}{|c|} 
構造形態 \\
\\
綏傾斜 \\
護岸
\end{tabular}} & 被災 & 被災形態 \\
\hline \multirow{2}{*}{1} & \multirow{2}{*}{2004} & \multirow{2}{*}{$8 / 19$} & & & 56.4 & $\begin{array}{l}\text { 被覆ブロックの散乱・(破壞) } \\
\text { 後砂の流出 }\end{array}$ \\
\hline & & & $\begin{array}{l}\text { 安宅新町地先 } \\
\text { (B区間) }\end{array}$ & & 40.5 & $\begin{array}{l}\text { 被覆ブロックの散乱・(破壞) } \\
\text { 後背砂の流出 }\end{array}$ \\
\hline \multirow{2}{*}{2} & \multirow{2}{*}{2005} & \multirow{2}{*}{$2 / 21$} & $\begin{array}{l}\text { (1)日末 } \\
\text { 安宅新士 }\end{array}$ & $\begin{array}{l}\text { 直立堤 } \\
\text { 消波工 }\end{array}$ & 125 & $\begin{array}{l}\text { 直立堤本体の倒壊（破壊）・天端楩没 } \\
\text { 後背砂の流出・消波ブロックの散乱 }\end{array}$ \\
\hline & & & (2)浜佐 & $\begin{array}{l}\text { 直立堤 } \\
\text { 消波工 }\end{array}$ & 20 & \begin{tabular}{|l|} 
天端陥没・後背砂の流出 \\
消波ブロックの散乱
\end{tabular} \\
\hline 3 & 2005 & $11 / 30$ & 安宅新地先 & $\begin{array}{l}\text { 直立堤 } \\
\text { 消波工 }\end{array}$ & 200 & $\begin{array}{l}\text { 直立堤本体の倒壊（破壊）・天端樎没 } \\
\text { 後背砂の流出・消波ブロックの散乱 }\end{array}$ \\
\hline \multirow{2}{*}{4} & \multirow{2}{*}{2006} & $1 / 23$ & 浜佐美地先 & \multirow{2}{*}{ 直立堤 } & \multirow{2}{*}{120} & \multirow{2}{*}{$\begin{array}{l}\text { 直立堤本体の倒壊（破壊）・天端陥没 } \\
\text { 後背砂の流出・消波ブロックの散乱 }\end{array}$} \\
\hline & & $3 / 31$ & 同地点増破 & & & \\
\hline \multirow{2}{*}{5} & \multirow{2}{*}{2007} & $1 / 7$ & 浜佐美地先 & \multirow{2}{*}{ 直立堤 } & \multirow{2}{*}{227.8} & \multirow{2}{*}{$\begin{array}{l}\text { 直立堤本体の倒壊（破壊) · 天端陥没 } \\
\text { 消波工の沈下・後背砂の流出 }\end{array}$} \\
\hline & & $2 / 15$ & 同地点増破 & & & \\
\hline 6 & 2007 & $10 / 20$ & 安宅新地先 & $\begin{array}{l}\text { 緩傾斜 } \\
\text { 護岸 }\end{array}$ & 36.4 & $\begin{array}{l}\text { 左 : 護岸前面の洗掘・被覆プロックの沈下 } \\
\text { (中 } 下 \text { 部被災) } \\
\text { 右 : 空洞発生・フトン篭との間に空洞 }\end{array}$ \\
\hline 7 & 2007 & $11 / 12$ & 加賀市篠原地先 & $\begin{array}{l}\text { 緩傾斜 } \\
\text { 護岸 }\end{array}$ & 143 & $\begin{array}{l}\text { 天端陥没・空洞発生・被覆ブロックの沈下 } \\
\text { (上部被災) 2か所・基磷の沈下 }\end{array}$ \\
\hline 8 & 2010 & $1 / 4$ & 安宅新地先 & $\begin{array}{l}\text { 直立堤 } \\
\text { 消波工 }\end{array}$ & 64 & $\begin{array}{l}\text { 天端陥没・後背砂の流出・消波工の沈下 } \\
\text { 直立堤底下版下の土砂の吸出し }\end{array}$ \\
\hline
\end{tabular}

石川海岸の背後には北陸自動車道や石川の産業を支える 多くの企業が立地する地理的条件にあり, 古くから離岸 堤, 直立堤あるいは緩傾斜護岸などによる海岸保全が行 われてきている。しかし，夏季における台風や冬季にお ける日本海の厳しい高波浪により，海岸構造物が繰り返 し被災している状況で，現在も片山津海岸保全対策技術 検討会（北陸地方整備局事業評価監視委員会，2014）の もと, 海岸保全対策が議論されている.

\section{(2) 海岸保全施設の被災特性}

石川海岸小松・片山津工区における2004年から2010年 までに発生した主要な被桨について，被桨調査報告書 （北陸地方整備局金沢河川国道事務所，2013）を参照し て, 発生地点と発生日をさらに海岸構造物の構造形態, 被災延長，被災形態などを整理した結果を図-2および表 -1示す。この間に発生した被災件数は合計9件で，直立堤 の被災が6件，その内消波工が堤体前面で機能している と考えられる事例（表中の構造形態に消波工と記載）は
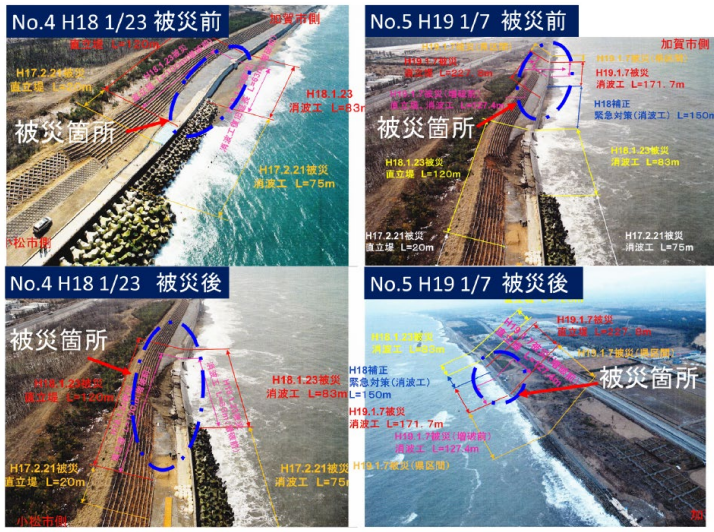

図-3 直立提の被災状況(表-1中のN 0.4およびN 0.5の場合) (北陸地方整備局金沢河川国道事務所, 2013)

4件で，消波工が施工されていないもしくは沈下散乱に よって機能しているとは考えられない事例は2件であっ た。なお，被災が発生した後復旧作業が完了する前に再 び波浪によって被桨し，被災延長が増大した事例も確認 されている.上述の4件の消波工を伴わない直立提の場 合，来襲波浪の作用下で構造部前面の前浜が消失し，堤 体を越流する越波流量の影響に伴う堤体背後域からの背 後砂の流失に伴うと思われる被災機構で堤体の天端陥没 や決壊等に至っているようである。図-3に表-1中のNo.4お よびNo.5の直立提の場合における被災前および被災後の 周辺状況の様子を示すが，来襲波浪が直接的に堤体へ作 用している状況下での堤体決壊に至る被災が確認できる。

\section{(3) 海象特性}

対象海岸に近接した現地海象計測地点のデータとし て，本研究ではNOWPHAS金沢港観測地点での波浪デー 夕を用いる。なお，石川海岸の沖合における波の主方向
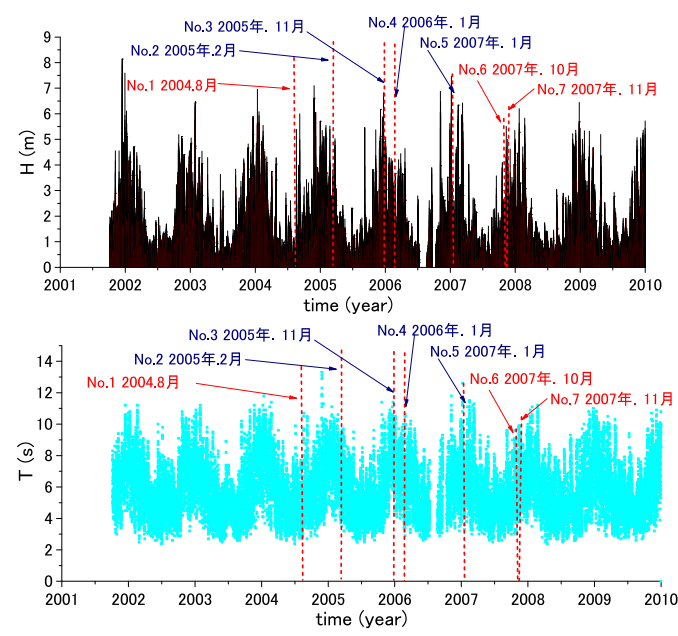

図-4 NOWPHAS金沢港観測地点で観測された有義波高(上段) と有義周期(下段) および2004年から2010年までの石川 海岸小松・片山津工区での被災発生状況 
はN N WからWであり, 年最大有義波高は5 8m程度に達 し, 通年の沿岸漂砂の卓越方向は西向き（図-2で右から 左）である（田中ら，1997）。図-4に2004年から2010年ま でに観測された有義波高および有義周期の時系列，さら に図-2㧍よび表-1に対応した被災発生状況（図中の点線 は被災発生年月日を表す）を示す。図より，冬期に打け る高波浪の来襲が顕著であることが確認できるが，堤体 の被災は暴浪期間の最大波高が来襲した直後に発生して いるとは限らないことも確認できる.

\section{3. 解析方法}

上述のように，近接した地点で繰り返し海岸構造物の 被災発生が確認された時と来襲する波浪の海象特性を比 較した場合，堤体の被災が例えば設計波高を上回るよう な大きな波高の来襲直後には発生していない，両者に一 対一の対応関係がある場合は，設計波高をべースとした 堤体の設計方法（合田，2008）は有効となるが, 設計上 力学的な安定性が崩れる破壊状態と実際に発生する被災 との対応の相関は良好とは言えず，設計波を下回る波浪 の来襲で被災が発生していることが分かる。この理由の 一つとして, 砂や砂利, さらにコンクリートの複合構造 となる堤体と来襲する波浪との相互干渉により, 前浜の 変形, さらに堤体の材料境界が有する脆弱性などに起因 した構造断面の変化など施工当初からの経年変化が考元 られる。これに対して, 堤体周辺地盤の特性および来襲 波浪の特性を時々刻々とモニタリングし, 例えば破堤限 界值（山本ら，2005）に至る状況を予測することも被災 発生予測として有効と考えられるが，堤体の規模および その延伸距離を考えた場合には現実的とは言い難い.

本研究では, 近接する海岸構造物が繰り返し被災を受 けている海岸に拝いて，来襲波による経年的な施設への 影響を波浪の履歴特性から考慮して今後の被災の発生予 測を実現しょうとするものである。解析手法の方針は, 来襲波のエネルギーや越波流量が被災時までにどの程度 累積されていたかを来襲波については波高の自乗值と暴 浪の継続時間との積による蓄積量, 越波流量についても 同様な積により計算し, 被災発生の目安となる累積指標 值の推定を試みる。具体的には以下のようである.

まず, 波浪の履歴特性を抽出するにあたって, NOWPHASによって取得された有義波高デー夕を図-5に 示すように間瀬ら（2008）の暴浪のモデル化に倣って整 理する。このとき, 暴浪は有義波高が $2 \mathrm{~m}$ 超える場合と 定義し, 各暴浪中の最大波高 $\mathrm{H}$ と暴浪継続時間丁を抽出 する。来襲波浪の波高履歴特性として, 波エネルギーに 比例する $\mathrm{H}^{2}$ と暴浪継続時間 $\mathrm{T}$ との積により暴浪期間の総 波エネルギー量を $\mathrm{H}^{2} \mathrm{~T}$ によって定義して算定する。この 場合，暴浪期間の波高の変動を最大波高によって代表さ

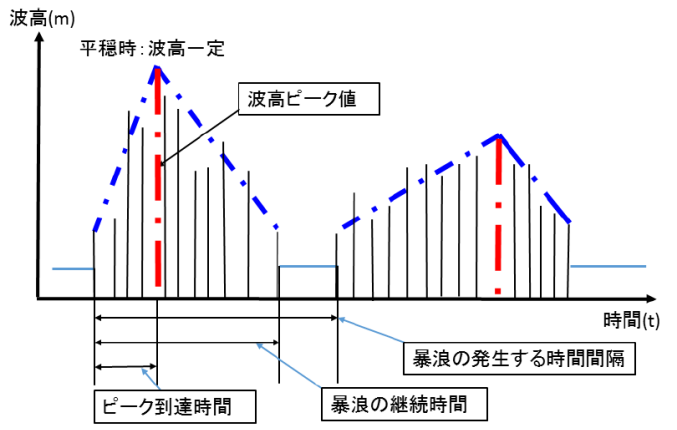

図-5 2 NOWPHAS金沢港観測地点での波浪デー夕に対する暴 浪のモデル化(間瀬ら, 2008)

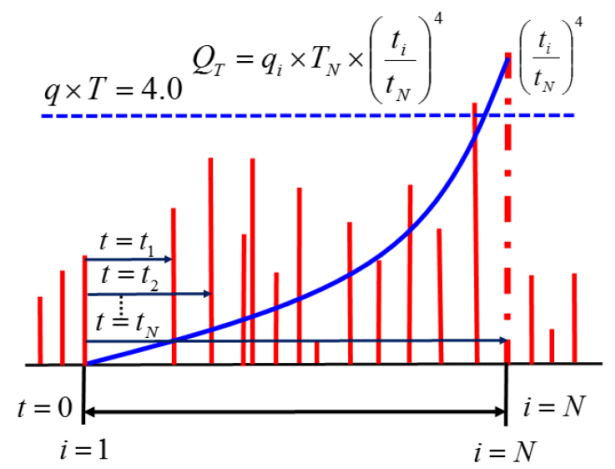

図-6 連続的な暴浪の発生時から当該の対象時間の経過に反 比例して減少する影響関数の導入

せるため安全側に立った設定となっている.

一方，堤体の被災発生に起因する要因として，来襲波 浪の大きさのみならずそれに伴う堤体背後への越流水量 が関連していることに鑑み, 暴浪時ピーク波高に応じた 対象構造物への越波流量 q を合田ら（1975）および高山 ら（1982）の算定法で抽出し，暴浪継続時間丁との積か ら暴浪期間の総越波流量 qT 算定した。この場合も, 波高の場合と同様に安全側の設定になる。

さらに，図-6に示すように，過去のある時点 $\mathrm{t}_{\mathrm{i}}=0$ から 被災発生付近までの時間 $\mathrm{t}_{\mathrm{i}}=\mathrm{N}(\mathrm{i}=0,1 \ldots \mathrm{N} ; \mathrm{i}$ はモデル化 された各暴浪の発生順を表し, $\mathrm{t} は$ 各暴浪での最大波高の 発生時間に対応する）に過去から遡って蓄積される各暴 浪期間中の総波エネルギー量 $\mathrm{W}_{\mathrm{T}}$ あるいは総越波流量 $\mathrm{Q}_{\mathrm{T}}$ は, $\mathrm{t}_{0}$ からの時間の経過 $\mathrm{t}_{\mathrm{i}}$ の増加に伴って蓄積量の要素 としての影響が減衰するものとして, 時間影響関数 $\left(\mathrm{t}_{\mathrm{i}} /\right.$ $\mathrm{t}_{\mathrm{N}}$ ）のべき乗を導入して波浪の履歴特性を考慮した。こ のべき乗については後述するように, 試行計算からその 值を同定している.

なお，対象海岸の面的な広がりに伴う海象条件の変化, 場所による断面㧍よび材料特性の変化, さらに暴浪期間 中の波浪抢よび越波流量の変化などの詳細な条件の取り 込みについては今後検討を進めたい． 


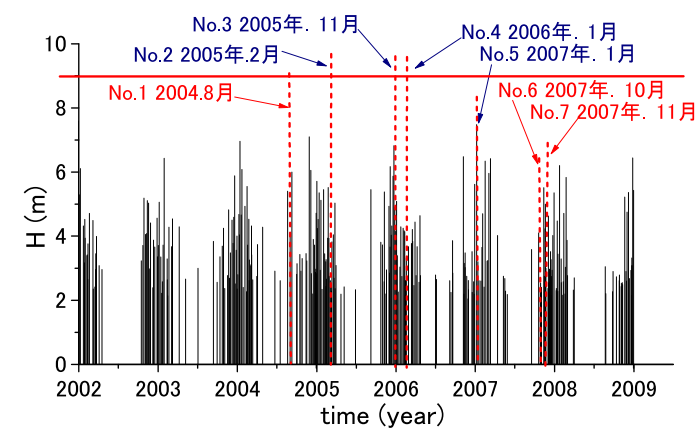

図-7 モデル化された暴浪時最大波高と2004年から2010年ま での石川海岸小松・片山津工区での被災発生状況

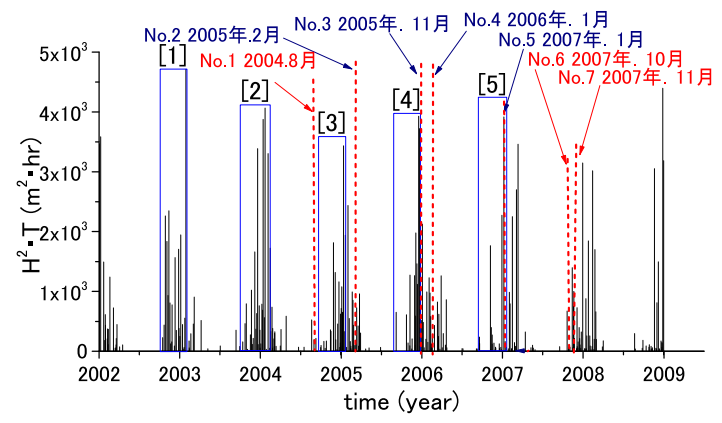

図-8 各暴浪期間の波エネルギー量と2004年から2010年まで の石川海岸小松・片山津工区での被災発生状況

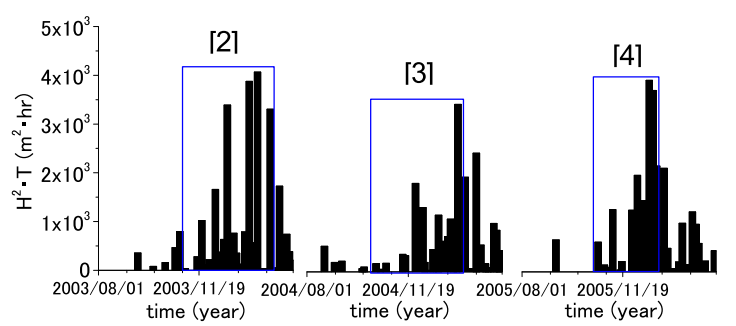

図-9 影響時間係数の対象範囲

表-2 各波高履歴に基づいた被災指標設定の試み

\begin{tabular}{c|c|c|c|c|c}
\hline No & {$[1]$} & {$[2]$} & {$[3]$} & {$[4]$} & {$[5]$} \\
\hline $\mathrm{W}_{\mathrm{T}}\left(\mathrm{m}^{2} \cdot \mathrm{hr}\right)$ & 6998 & 10986 & 7332 & 10739 & 5957 \\
\hline
\end{tabular}

\section{4. 来襲波浪の波高履歴特性を用いた被災予測}

図-4の有義波高デー夕を間瀬ら（2008）の暴浪のモデ ル化に倣って整理し, 各暴浪時の最大波高 $\mathrm{H}$, さらに暴 浪継続時間丁を用いて算定した各暴浪期間の総波エネル ギー量 $\mathrm{H}^{2} \mathrm{~T}$ と図-2および表-1に対応した被災発生状況を 同時に図示した結果を図-7に図-8に示す。当然ではある

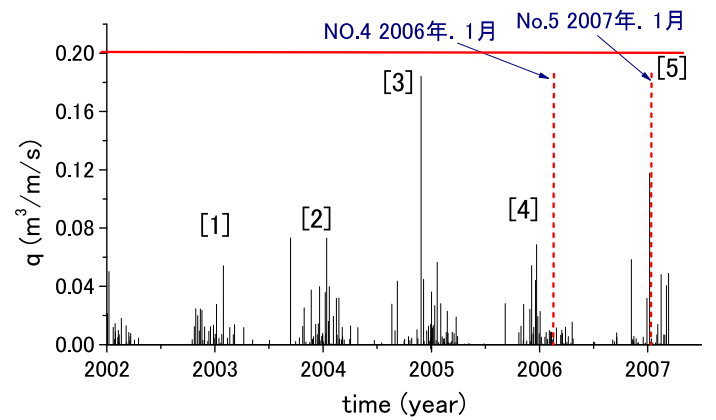

図-10 暴浪時最大波高に基づいた越波流量と2004年から2010 年までの石川海岸小松・片山津工区での被災発生状況

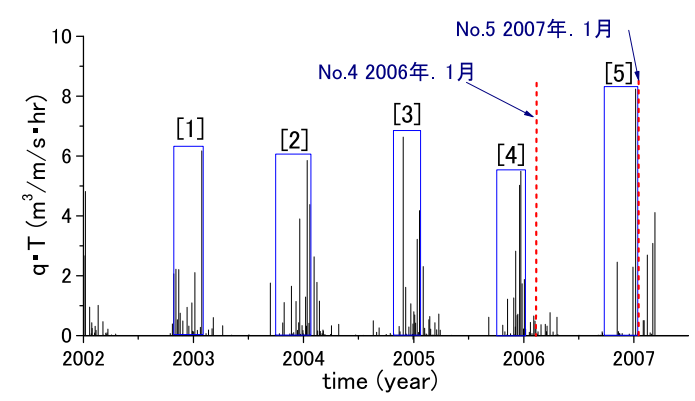

図-11 各暴浪期間の総越波流量と2004年から2010年までの石 川海岸小松・片山津工区での被災発生状況

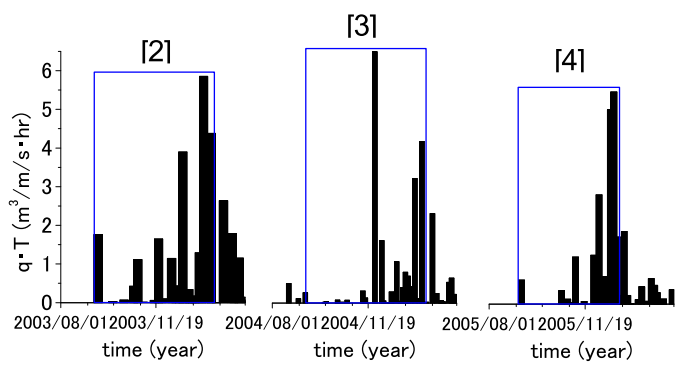

図-12 影響時間係数の対象範囲

表-3 越波流量履歴に基づいた被災指標設定の試み

\begin{tabular}{c|c|c|c|c|c}
\hline $\mathrm{No}$ & {$[1]$} & {$[2]$} & {$[3]$} & {$[4]$} & {$[5]$} \\
\hline $\mathrm{Q}_{\mathrm{T}}\left(\mathrm{m}^{3} / \mathrm{m} / \mathrm{s} \cdot \mathrm{hr}\right)$ & 7.8 & 12.4 & 9.8 & 12.9 & 10.1 \\
\hline
\end{tabular}

が，図-7に示した波高と被災発生状況との間には，図-4 の場合にそうであったように，堤体の被災と暴浪期間の 最大波高の来襲との間に優位な相関関係は見出し難い.

各暴浪期間の波エネルギー量を対象とした図-8の場合 でも，個々の $\mathrm{H}^{2} \mathrm{~T}$ の值で，例えば非常に大きな $\mathrm{H}^{2} \mathrm{~T}$ の発 生の直後に被災が発生するといった両者との間に優位な 相関は見られない. 
後述する越波流量の履歴特性を用いた被災予測でも 述べるが, 本研究では近接地点に繰り返し被災の発生 例では, 図-9に $W_{\mathrm{T}}$ の説明図として, 表-1中のNo.4およ びN 0.5 の消波工を伴わない直立提を対象として予測指 標の同定を試みるが, 被災直後から過去の暴浪発生ま でに遡って時間影響関数を取り入れた被災指標の同定 を試みたが，いずれの時間影響関数のべき乗の值の場 合でも，被災と非被災を識別できる指標の同定には至 らなかった。

\section{5. 来襲波浪の越波流量履歴特性を用いた被災予測}

波高の特性を用いた越波流量は堤体前面に消波工が 設置される場合されない場合で算定指標が異なる、本研 究では, 比較的短い期間で近接箇所における被災が確 認されている表-3中のN 0.4およびN 0.5の消波工の設置 を伴わない，もしくはその効果が期待できない場合を 対象として, 来襲波浪に伴う越波流量を整理する。

図-10に，モデル化された暴浪時最大波高発生時の波 高を用いて算出した越波流量の時間変化を示す，消波 工を伴わない直立提構造の場合, 越波による被災指標 としては, 合田ら（1970）による $\mathrm{q}=0.2 \mathrm{~m}^{2} / \mathrm{s}$ が知られ ているが, 図より対象期間に抒いては越波流量の值が この指標值を下回っている状況で被災が発生している ことが分かる。また，図-7および図-8の場合と同様に, 大きな越波流量の発生直後に被災は必ずしも発生して いない.

次に, 各暴浪の継続時間 $\mathrm{T}$ を用いて各暴浪毎の越波 総流量qTを整理した結果を図-11に示す。図より, N o.4の場合は比較的大きなqTが連続して発生した後 に, N o.5の場合は, 極端に大きな単発の qT の発生後 に被災が発生していることが分かる，そこで，No.4の 被災に対しては, 閾值として qT=4 を上回る值の発生 時点から最初の暴浪発生までに遡って, 越波流量履歴 に基づく被災指標の計算を時間影響関数のべき乗を変 化させて各年度（図-12に各年度における対象時間 $\mathrm{t}_{\mathrm{N}}$ の 範囲を拡大表示する）で行った，時間影響関数に4乗 を用いた場合に, 被災発生の有無を識別できる指標值 が $12.9 \mathrm{~m}^{2} / \mathrm{s} \cdot \mathrm{hr}$ として算定された（表-3に被災が発生 しなかった場合の計算值を示す）示す。なお，上述の ような履歴に依存しない場合の被災指標值の同定につ いては, 他の構造形態の場合も含めて今後検討を進め る

\section{6. 結 論}

本研究では, 設計波を下回るような来襲波の条件下で 繰り返し海岸保全施設の被災の発生が確認されている海 岸での被災事例を参照して, 波浪の履歴特性を取り入れ
た被災の発生予測モデルの構築を試みた。 以下に本研究 で得られた結論を要約する。

海岸構造物の被災の発生に対して, 設計波高とは別に, 新たに来襲波浪の暴浪時最大波高，暴浪継続時間，暴浪 最大波高に対応した越波流量を用いた波エネルギーや越 波流量の各暴浪期間での蓄積量, さらに被災発生から 遡って初期の暴浪の開始時刻から時間経過と共に減衰す る時間影響関数を導入して過去の波浪履歴を取り込んだ 波エネルギーや越波流量の蓄積量を被災発生予測の指標 とするモデルの構築を試みた。

対象とした石川海岸小松・片山津工区に扔ける直立堤 の被災発生予測に対しては, 越波流量の履歴特性を考慮 したモデルによって被災発生の予測を可能とし得る指標 を得ることができた．本研究で提案した被災発生予測モ デルを用い，過去の波浪デー夕を用いて被災発生の可能 性に関する追算を行い，被災の発生に対応した波浪，越 波流量およびその継続時間との関連性を明らかにするこ とへの応用が考えられる。

\section{参 考 文 献}

大河原満・橋本 宏・斉藤 雄三郎（1983）：被災事例から見 た海岸堤防・護岸に関する一考察, 海岸工学講演会論文 集, Vol. 30, p. 264-268.

加藤史訓・野口賢二・諏訪義雄（2011）：海岸堤防・護岸の 被災に関する実態調査，土木学会論文集B3（海洋開発）, Vol. 67, No. 2, pp.I 7-I 12 .

合田良実（1970）：防波護岸の越波流量に関する研究，港湾 技術研究報告, Vol.9, N o.4, pp.3-41.

合田良実・岸良安治・神山 豊（1975）：不規則波による防 波護岸の越波流量に関する実験的研究，港湾技術研究報 告, Vol.14, No.4, pp.3-44.

合田良実（2008）：耐波工学 港湾・海岸構造物の耐波設計, 鹿島出版会, $430 \mathrm{p}$.

高山知司・永井紀彦・西田彦一（1982）：各種消波工による 越波流量の減少効果, 港湾技術研究所報告, Vol.21, No.2, pp.151-205.

田中茂信 - 佐藤憤司 - 川岸眞一 石川俊之 - 山本吉道 $\cdot$ 浅野 剛 (1997) : 石川海岸に打ける漂砂機構, 海岸工学論文 集, Vol. 44, pp. 661-665.

北陸地方整備局事業評価監視員会: 海岸事業の再評価資料, http://www.hrr.mlit.go.jp/johokokai/hyouka/hyouka_top. html（オンライン）参照2014-05-14.

北陸地方整備局金沢河川国道事務所（2013）：石川海岸被災 状況写真等資料.

間瀬 肇・安田誠宏・勝井伸悟 (2008)：海浜変形評価に供 する長期間の波浪・風時系列のモデル化一上越地域海岸 を対象としてー, 海岸工学論文集, Vol. 55, pp. 426430.

山本吉道・川島 理・諏訪義雄（2005）：高波と津波による 海岸施設の破壞機構と破堤限界值の現地海岸適用, 海岸 工学論文集, Vol. 52, pp. 1281-1285.

山本吉道・南 宣孝 (2009)：高波による海岸堤防破壊メカ ニズムの実験的研究, 土木学会論文集B2（海岸工学）, Vol. 65, No. 1, pp. 901-905.

山本吉道・成吉兼二・比嘉了規 (2011)：海岸堤防・護岸の 被災限界の研究, 土木学会論文集B3 (海洋開発), Vol. 67, No. 2, pp. I_100-I 105. 